\title{
Migration as Pursuit of the Social Determinants of Health
}

\section{Costello (Michael M. Costello)}

Department of Health Administration and Human Resources, University of Scranton, PA, USA.

\section{E-mail address:}

michael.costello@scranton.edu

\section{Reprint address:}

Michael M. Costello

Department of Health Administration and Human Resources

University of Scranton, PA

USA

Source: Clinical Social Work and Health Intervention

Volume: 12

Issue: 4 Pages: $74-77$

Cited references: 13

\section{Reviewers:}

Roberto Cauda

Institute of Infectious Diseases, Catholic University of the Sacred Heart, Rome, IT

Daria Kimuli

Catholic university of Eastern Africa, Nairobi, KE

\section{Keywords:}

Migrants. Refugees. Social Determinants of Health.

\section{Publisher:}

International Society of Applied Preventive Medicine i-gap

CSWHI 2021; 12(4): 74 - 77; DOI: 10.22359/cswhi_12_4_09 (C) Clinical Social Work and Health Intervention

\section{Abstract:}

Immigrants, refugees and displaced persons are often a source of political and diplomatic tensions as they move away from their homelands. Their movement is often viewed with hostility by those they encounter in their travels. But most of these travelers are merely seeking a better life as evidenced by pursuit of social determinants of health. Their right to this pursuit is reflected in international law and by recognition of principles of social justice.

\section{Introduction}

In recent years, approximately 60 million individuals have been classified as immigrants, refugees or displaced persons at a given time. Whether these people are moving across international borders or within their own homeland, some are moving of their own volition while oth- ers feel compelled to move because of conditions in their home locales.

Those who immigrate are not always made to feel welcome on their journey. Whether they move within their own nations as displaced persons or cross international borders in pursuit of better lives as immigrants or refugees, they often 
face forceful opposition from the native populations they encounter. Political opposition often confronts those seeking asylum and temporary or permanent residence in a new nation or locale within their home nations. They are often viewed as invaders by those whose territories they move through or to.

A closer examination reveals that immigrants are not seeking to do harm to those they encounter. Rather they tend to seek improvement in their lives by pursuing social determinants of health often denied to them in their homelands. Their right to pursue these social determinants is supported in international law and reflected in the principle of social justice.

\section{The Migratory Process}

People have moved about on the earth since the earliest of times. Marceca (2017) believes the migratory phenomena referred to as „Out of Africa II" started in North-Eastern Africa 70,000 years ago. Shah (2020) writes of pre-historic migration from Asia to an expanse of the Pacific Islands beginning approximately 5,000 years ago. Between the years 1880 and 1930 she writes that more than 27,000,000 people entered the US (ibid).

In general, migration occurs because people seek a better life, believing that their destination will represent an improvement over the place from which they came. Rosen \& Young (2016) distinguish between migrants and refugees or asylum seekers. Although both participate in the migratory process, they define refugees as those „who are fleeing armed conflict or persecution, and who would be in danger if forced to return to their own countries." Migrants are usually seeking to improve their lives by finding work, pursuing education, or reuniting with family members. They are generally free to return to their home countries if they so desire.

According to Marceca (2017), the migratory phenomenon have been widely examined from historical, social, economic, and cultural perspectives, (but) health and health care perspectives are understudied." He writes further of the need to analyze the health needs of migratory populations, the education and training of health social workers providing care to migrants and the necessity of evaluating ,health outcomes of the migrant population and the impact of adopted health policies" (ibid).
The World Health Organization (2019) published a draft global action plan entitled „Promoting the health of refugees and migrants." Among its pronouncements is the following:

Although their treatment is governed by separate legal frameworks, refugees and migrants are entitled to the same universal human rights and fundamental freedoms as other people. Refugees and migrants also face many common challenges and share similar vulnerabilities. The Secretariat will focus on achieving universal health coverage and the highest attainable standard of health, as mandated in WHO's Constitution, for refugees, migrants and host populations within the context of WHO's Thirteenth General Program of Work, 2019-2023) (ibid)

Although the WHO's pronouncements are laudable, Gostin (2019) writes that its achievements in the field of immigrant health have been less stellar. He writes:

To achieve its goals, WHO will have to persuade governments to treat migrants humanely, while affording them equal health and social benefits. But in a world of rising nationalistic populism, that is a hard sell. Governments view asylum-seekers as culturally and religiously incompatible with their country's cultural values, or as a financial burden they don't want (ibid).

Immigrant populations may be expected to encounter health problems related to their locations away from home. More than three million displaced Syrians living in crowded camps and informal settlements in northwestern Idlib province might have been exposed to COVID-19 when a hospital physician was diagnosed after having contact with up to 300 patients (Coles \& Osseiran). The lack of PPE at the hospital combined with poor sanitation in the camp and settlements increased the fear of spreading infection (ibid).

A refugee camp named Moria, on the Greek Island of Lesbos, further illustrates the COVID19 related health risks forced by refugees. Migrants from Syria, Afghanistan, Iraq and other countries inhabited a camp of tents, housing containers and ramshackle self-made shacks squeezed together in close proximity (Abdulrahin, 2020). A 17-year old asylum seeker living in the camp said:

With the coronavirus you have to avoid going to crowded places, keep yourself clean, don't go outside. In Moria camps you have to go outside. 
For toilet, for shower, for food. And every time you go outside you are in a really, really big crowd of people (ibid)

In addition to health problems that migrants may encounter in holding areas or sometimes at their destinations, their journey may also be problematic. While in transit, they may also be exposed to unsanitary conditions that may facilitate the spread of disease and treatment capabilities may be severely limited for numerous reasons.

However, the migrants' point of origin may also prove detrimental to their health. The World Health Organization (2012) defined social determinants of health as ,the conditions in which people are born, grow, live, work and age. These circumstances are shaped by the distribution of money, power and resources at global, national and local levels“ (ibid).

Among the specifically identified factors are:

- Income and social status

- Education

- Physical environment

- Social support networks

- Genetics

- Health services

- Gender

(WHO, 2017)

The „northern triangle“ of Central America represents an interesting geographical region for the study of immigration. Comprised of El Salvador, Honduras and Guatemala, the region has long comprised of both a route of immigration to the USA as well as a source of an immigrant population. Shah (2020) writes that European and African immigrants have long traveled to South America and then made their way north through Central America in transit to Mexico and the United States. In more recent times, a larger segment of the „,iron triangle“ population has become part of the migratory push northward, to include unaccompanied minor children sent by their parents.

The humanitarian crisis in Syria is a glaring example of the plight of refugees and displaced persons. According to the Brookings Institution (2018) over half the Syrian population has been forcibly displaced. A little less than one quarter of the world's population of 25 million refugees are from Syria and residing in Jordan, Lebanon and Turkey. Syrians also account for 6 million of the world's 40 million internally displaced per- sons, still remaining within the nation's borders

Syrian refugees and internally displaced persons are victims of Syria's long simmering civil war. Central American refugees have made their way to the USA, primarily because of living conditions in their home countries which equate to the common understanding of the social determinants of health.

The Immigration Forum (2019) claims that the most recent research findings indicate that immigrants strive to come to the US because of „push factors" that cause them to leave their countries of origin"... primarily because of real fears about their futures" (ibid). These include: „violence, gender inequality, political corruption, environmental degradation and climate change, as well as lack of access to adequate health care and education" (ibid).

Zoe Carpenter (2021) writes:

What is happening now is not so different from previous spikes in the number of children crossing the border in 2014 during Barack Obama's Presidency, and in 2019, under Donald Trump. Then as now, many are fleeing violence and poverty ....In Guatemala the situation for children is increasingly dire because of last year's hurricanes, the economic impact of COVID-19 and crop failures linked to drought, all of which has contributed to food insecurity.

(The Nation, April 22, 2021).

\section{Internationa Legal Recognization}

Access to social determinants of health is an evolutionary concept reflected in international and public health law. An examination of the causes of migration reveals that immigrants and displaced persons are often forced to move to new locations as part of their efforts to access social determinants of health.

Lawrence Gostin (2014) writes that he views much of international health law as an

extension of human rights law:

„....global health law encompasses the concept of health as a fundamental human entitlement, as well as encompassing multiple legal regimes outside the health sector. The right to the highest attainable standard of physical and mental health embedded within a large network of human rights, norms, institutions, and processes is a growing and expansive field that intersects with health 
The International Covenant on Economic, Social and Cultural Rights 1966 became effective 10 years later on January 3, 1976. As of October, 2010, 160 states had ratified the covenant. Among the rights specified in the covenant is „right to highest attainable standard of physical and mental health" (Article 12)

Dixon et al. (2011) write of the obligation ,a State owes to another State with regard to the treatment of that other State's nationals within the first state's territory." The authors indicate that a ,denial of justice“ may result in ,,an action on the international plane.“" (p. 439).

At the southern US border with Mexico, unaccompanied children have presented themselves for asylum in the US. The United Nations' Convention on the Rights of the Child (1989) stipulates that ,states parties shall strive to ensure that no child is deprived of his or her right of access to.....health care services.“ (Mark, ed, p. 82)

More specifically, the social determinants of heath have been drawing increased scrutiny as evidenced by the adoption of General Covenant No 14 by the United Nation's Committee on Economic, Social and Cultural Rights (Marks, p. 82). The comment was in response to the above-mentioned Article 12 of the International Covenant concerning the Right to the Highest Attainable Standard of Health. The comment reads in part:

The Committee interprets the right to health, as defined by Article 12, as an inclusive right extending not only to timely and appropriate health care but also to the underlying determinants of health, such as access to safe and potable water and adequate sanitation, an adequate supply of safe food, nutrition and housing, healthy occupational and environmental conditions, and access to health-related education and information... (ibid p. 84)

\section{Conclusion}

Support for immigrant, refugee and displaced person's pursuit of the social determinants of health can be found in international law. Although international law may sometimes be imprecise and subject to national law restrictions, it does provide authoritative and moral guidance on the migratory process. While a right to receive health care services has been long recognized for the migrant population, it would appear that the pursuit of the social determinants is now recognized as well.
Future research should focus on specific migratory experiences, the access to health care provided to migrant populations and realization of the social determinants by migrants. Increased emphasis should be placed on efforts to expand national legal protections for migrants.

\section{References}

1. ABDULRAHIM R (2020) Cramped Spaces Raise the Risks in Refugee Camps. Wall Street Journal, March 27, 2020, p. A9.

2. CARPENTER Z (2021) Climate Change Will Force Us to Rethink Migration and Asylym www.scientificamerican.com_Retrieved April 23, 2021.

3. COLES I, OSSEIRAN N (2020) Covid Threatens Syrian Rebel Area. Wall Street Journal July 11-12, 2020.

4. DIXON M, MCCORQUODALE R, WILLIAMS S (2011) Cases and Materials on International Law. Fifth Edition. Oxford: Oxford University Press, 2011.

5. GOSTIN L (2014) Global Health Law. Cambridge, MA: Harvard University Press, 2014.

6. IMMIGRATION FORUM (2019) Push or Pull Factors: What Drives Central American Migrats to the US. www.immigrationforum. org Retrieved March 28, 2021.

7. KARASAPAN O (2018) The Challenges in Providing Health Care to Syrian Refugees. www.brookings.edu Retrieved February 19, 2020.

8. MARCECA M (2017) Migration and Health from a Public Health Perspective. INTECH.

9. MARKS S ed (2006) Health and Human Rights: Basic International Documents. Cambridge, MA: Francois-Xavier Bagnoud Center for Health and Human Rights. 2006.

10. ROSEN M, YOUNG A (2019) Who Are Refugees and Migrants. London: Wayland. 2019.

11. SHAH S (2020) The Next Great Migration. New York: Bloomsbury Publishing. 2020.

12. WORLD HEALTH ORGANIZATION (2017) Determinants of Health 3 February 2017. www-who-int Retrieved May 19, 2021.

13. WORLD HEALTH ORGANIZATION (2019) Promoting the Health of Refugees and Migrants. Draft Global Action Plan. April 25, 2019. www-who-int Retrieved May 19, 2021. 